Sign Systems Studies 30.1, 2002

\title{
On the zoosemiotics of health and disease
}

\author{
Aleksei Turovski \\ Tallinn Zoo, Paldiski mnt 145, 13522 Tallinn, Estonia \\ e-mail: p.turovski@tallinnlv.ee
}

\begin{abstract}
The main feature of the signs of health in the animal habitus and behaviour can be characterised as the readiness to adequately (for a species) serve the need for impression (in animalistic elements of the Umwelt). The signs of disease, however multifarious and diverse, generally display certain lack of Umwelt-oriented attentiveness, alertness. Attention of deeply afflicted animals is strongly Innenwelt-oriented; and in some species a set of such signs, suggesting sickness or mortal disease is used as a set of traits in the mimicry of dying. The semiotic factors in health-disease relationships are apparently connected with intuition - like responses creating in the semiosphere a structure of Umwelt-Innenwelt polarized tensions, important in ecological and evolutional developments.
\end{abstract}

Speak roughly to your little boy,

And beat him when he sneezes:

He only does it to annoy,

Because he knows it teases.

Lewis Carrol (1924: 71)

... but he (the dragon) was most unmistakably alive, and proved it by having a hearty appetite and an evident enjoyment of life.

G. K. Chesterton (1970: 203)

One of the generally shared human beliefs about the dangerousness of animals is that some healthy specimens of the best "armed" species, that is well equipped with harmful facilities, are the most dangerous ones. However, this notion is not always true, at least where the danger to modern men is concerned. It would be truer to notify that in 


\section{Aleksei Turovski}

the majority of situations, leading to encounters with humans, just the sick animals, whether injured, poisoned, traumatized to a certain degree, or afflicted by infectious disease would prove to be potentially the most dangerous ones due to the severe changes in their behaviour in the first place. A healthy tiger, panther, rattle snake, cobra, black widow spider (Latrodectes sp.), hornet etc are the most able experts in avoidance of humans even in anthropogenically stressed environment, to say nothing about the natural habitats. But the probability of undesirable contact with sick animals, e.g. injured snakes, poisoned wasps, ornithosis infected birds, plague afflicted rodents and a most striking example, I trust, with various species of rabies affected mammals, could be quite high, in the vicinity of nidus areas at least. The behavioural changes, induced and vectorized by pathogenic factors ranging from traumas to viruses and toxins, produce profound effects on the continuum of ecological interactivities including interand intraspecific competition, predator-prey relations, foraging strategies, mate choice, parent-offspring relationships etc. An excellent compendium on these and related topics is presented in the volume edited by Nancy E. Beckage (1997); and also in the monograph by Robert Poulin (1998) the theme of the significance of behavioural deviations resulting from parasite-host interactions in the evolutionary ecological aspects is presented very revealingly. However, the spectrum of behavioural shifts and deviations induced by and related to pathological events and developments ranges on a scale so large, that it presents an irresistable challenge: to try a semiotic approach to those phenomena that is to make a behavioural sign-structure analysis of ecological fitness in animal associations. It is quite obvious that the biological norm in case of any animal species is much larger than the veterinarian/medical one and the notion of an absolutely healthy animal or human being is just as formal as a notion of statistically average person. However we may presume that the signs of health are these pointing to a set of the traits of ecological fitness/suitability by ecoamplitudes, including physical strength and agility, full possession of specific forms of display such as adequate comfort behaviour, habitual appearance (high level of symmetry, specific pattern and brightness in coloration etc.) and rituals in sexual, territorial and social behaviour. In the semiosis-process the signs of health are multifunctional factors which serve as means to attract and/or intensify, fortify and enhance the specific attention of cospecimens, of 
specimens of ecologically favourable associated species (e.g., of mutualists), in comfort, parental, sexual, foraging and defensive behaviour. At the same time these signs are means to fortify the repulsion or at least the discouragement of intra - as well as interspecific predators and competitors in the same behavioural aspects as stated above. So, the main feature of the signs of health could be described as readiness to adequately serve the need for impression (Turovski 2000) in animal elements of the umwelt as a holistic semiosystem.

It seems that nothing so conclusive could be proposed as a general definition of the signs of disease. The majority of various maladies have so many different and variable symptoms, arranged in innumerable syndromes, the appearance of which depends on immunocompetence of the specimen - ability in its turn being dependent on the genotype, age, sex, individual phenotypical particularities connected with learning, life history, climate, ration, etc. - that even such features as general distress are not universal enough to describe them. And for all that, animals in the main part are able to detect and recognize some of the sick cospecimens, mainly as estranged weaks or, perhaps, even as alienated ones, and also the sick/deficient specimens of prey and/or competitor species. Moreover, many species seem to be able to recognize the signs of certain maladies, not just the morbidity or great tiredness but the actual olfactory, acoustical and visual symptoms. The ultimate signs of disease are, perhaps, the symptoms of dying and of great pain, signs displaying nearly total lack of umwelt-oriented attentiveness, alertness. Attention of such deeply afflicted animals is mainly Innenwelt-oriented. Specimens in such a state are usually avoided not only by cospecimens but also by young and specifically experienced predators and scavengers. This corresponds with various cases, which possibly could be considered as mimicry in which "the mimic" performs a display of violent convulsions and spasms, revealing "total lack of attention" towards the outer world, so that the signs which the predator-selector recognises correctly as the marks of prey are inhibited in the filter of semiosis in the reverse feedback (Maran 2001) situation. Behavioural traits of this kind are observable in defence behaviour of some reptilians and mammals, including primates. Still, though a lot of examples are known of the mimicry of death (opossums, some snakes), in which mimics even produce highly specific odour (not of carrion, but of abnormally unclean and/or poisoned animal), I am not ready to 


\section{Aleksei Turovski}

declare, that the repelling behaviour described above, highly agonistic as it is, is definitely a "mimicry of dying". However, mimicry of dying or/and dead takes place in the behaviour of small reptiles and mammals mostly in North and Central America, where the rattle snakes are (or used to be) in abundance. The behavioural display of violent convulsion and images of horribly twisted corps suggests acute toxicosis in prey bitten by a rattle snake. For properly (to a degree) experienced predators such pattern of prey behaviour points, perhaps, to the high probability of the presence of preying rattle snake in the vicinity, which means that it is on its way here in search for its prey. Certainly, the highly and specifically experienced predators could remind unimpressed by such a display. But in Australia and South Asia, where respectively, tiger snakes' and cobras' preying habits are of the opposite pattern (instant kill, especially in preying on birds), the cases of the mimicry of death in convulsions are rare.

I would like to propose two more forms of behaviour connected with the signs of disease to be considered as, probable, cases of mimicry, both in the field of intraspecific activities. The first case is the mimicry of the healthy behaviour of very young, performed by older offspring or even young adults, suffering from minor injuries, traumatic and shocking experiences and/or under stress caused by early stages of some infections. Such changes in the behaviour often gain convenient parental responses in bears, hyenas and primates, at least from natural mothers.

The second case represents the imitation of sickness, the actual simulation in order to attract more attention. A particular case I would like to describe in brief took place in Tallinn Zoo in 1998. The young female chimpanzee Quinsey (5 years) was playing with me trough the bars of her cage, when I was distracted by a colleague who addressed me with some question. My attention had been averted from Quinsey for some minutes when I heard her coughing. To the trained ear the sound was unmistakably artificial: she was pretending being unwell. When my attention was restored to her, the coughing immediately ceased. She was quite healthy at this time, but a fortnight before Quinsey really had had a cold in her head and enjoyed a lot of very profitable attention from all of us. I checked on her "cleverness" from time to time for two months on and she never failed to use the trick, though all the time she was in splendid health. Certainly we cannot 
call every case of imitational behaviour by higher primates "mimicry", but in the case with Quinsey I certainly performed a dutiful "dupe".

Much more complicated forms of, so to say, "induced or inflicted conspicuity" can be found in the field of deviations in the habitus and behaviour of hosts, which are caused by specific activities of some parasites and result in the increase in the attractiveness of hosts either to predators (fish diplostomosis, gigantism in snails, parasitized by some trematods etc.) or to sexual partners (human and other species tuberculosis, for instance). It is a real challenge to recognize the unfit and unsuitable sexual partners, offspring (killed or abandoned if recognized), prey or leaders, whose incompetence is due to some disease. The ability to perform this kind of recognition and thereby to avoid or escape the dangers of contagious infections is connected with experience/learning in higher vertebrates at least, but in most successful individuals it seems to be based on some special kind of alertness, resembling very much the intuition as it is defined by $\mathrm{H}$. Eysenck:

a mode of cognitive functioning located at the opposite end of a continuum from logical thinking, characterized by speed and suddenness of reactions, small number of relevant facts known or considered, feelings of certainty about the conclusions reached, reliance on unconscious processes, not following the rule of logic, and relying on unusual associations and analogies. (Eysenck 1995)

In the encounter with a sick animal there often is still some short time to make intuitive decision on the following course of action; besides, such time exists for both parties of the contact. In many cases of predator - prey encounters the prey at least does not have time for anything else than impulsive actions and that even if the prey is lucky. So, the semiotic factors connected with health-disease relationships and related to intuition-like responses could, perhaps, play a considerable part in evolutional processes.

The signs of health displaying appeals, directed and addressed into umwelt and the signs of disease, searched for and defied by umwelt, concealed or very intricately used by the carrier or inducer, apparently create in the semiosphere a polarized structure of highly potent tensions significantly important in all aspects in ecological developments, offering special interest from evolutional aspect. 


\section{References}

Beckage, Nancy E. (ed.) 1997. Parasites and Pathogens: Effects on Host Hormons and Behavior. New York: Chapman and Hall.

Carroll, Lewis 1924. Alice's Adventures in Wonderland. London: William Heinemann.

Chesterton, Gilbert Keith 1970. The dragon at hide-and-seek. In: Green, Roger Lancelyn (ed.), A Book of Dragons. New York: Penguin Books.

Eysenck, Hans 1995. Chapter 5: Intuition and the unconscious. In: Eysenck, Hans, Genius: The Natural History of Creativity. Cambridge: Cambridge University Press, 170-201.

Maran, Timo 2001. Mimicry: Towards a semiotic understanding of nature. Sign Systems Studies 29(1): 325-339.

Poulin, Robert 1998. Evolutionary Ecology of Parasites: From Individuals to Communities. London: Chapman and Hall.

Turovski, Aleksei 2000. The semiotics of animal freedom: A zoologist's attempt to perceive the semiotic aim of H. Hediger. Sign Systems Studies 28: $380-386$.

- 2001. On the parasite's association as a vectorizing factor in biosemiotic development. Semiotica 134(1/4): 409-414.

\section{К зоосемиотике здоровья и болезни}

Основной чертой знаков здоровья в облике и поведении животных является готовность адекватно (для вида) удовлетворять потребность впечатления животных элементов среды (Umwelt). Знаки болезни при всем их разнообразии совокупно являют обшую недостаточность внимания к знаковым сигналам внешней среды (Umwelt). Внимание серьезно больных животных мощно ориентировано на сигналы самого организма (Innenwelt). Ряд видов использует знаки, указывающие на болезнь как набор признаков в мимикрии умирания. Семиотические факторы во взаимоотношениях “здоровье-болезнь" явно связаны с реакциями типа интуиции, создавая в семиосфере структуру напряжений, поляризованных по оси "Umwelt-Innenwelt", важную в экологических и эволюционных процессах. 


\section{Tervise ja haiguse zoosemiootikast}

Loomade välimuses ja käitumises on peamiseks tervise märke iseloomustavaks jooneks valmisolek adekvaatselt (antud liigi jaoks) rahuldada omailma loomse osa muljete tarvet. Haiguse märgid, kogu oma mitmekesisuse juures, ilmutavad üldiselt haige looma tähelepanu puudulikkust ümbruse märkide suhtes. Tõsiselt haigete loomade tähelepanu on valdavalt suunatud organismi sisekeskkonna (subjektiivse siseilma) signaalidele-märkidele. Rida liike kasutab haigusele viitavaid märke kui tunnuste komplekte suremise mimikris. 'Tervis-haigus' suhete semiootilised tegurid on ilmselt seotud intuitsiooni tüüpi reaktsioonidega, mis loovad semiosfääris "välisilm-siseilm" pingete teljestiku, mõjutades ökoloogiliste ja evolutsiooniliste protsesside käiku. 